BARBARA E. GOFF

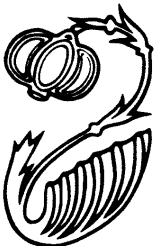

\title{
The Sign of the Fall: The Scars of Orestes and Odysseus
}

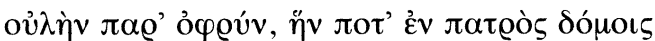

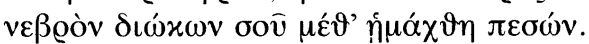

By $573,{ }^{1}$ Elektra has rejected all the Aeschylean tokens of recognition that are offered to her by the Old Man, and the play threatens to depart ever more wildly from its prescribed mythic course. It is retrieved by the scar that the Old Man notices at Orestes' eyebrow and points out to Elektra as proof, which she accepts, of Orestes' identity. The scar is necessary to the development of this drama, but it has not attracted much critical attention. ${ }^{2}$ Tarkow's article of 1981 laid out some basic approaches to the scar; in this paper I want to build on his work and to suggest more precisely what may be at stake in the account of this token.

Aristotle's Poetics claims that visible signs or tokens constitute the least satisfactory of all methods of plotting discovery and signal a failure in drama-

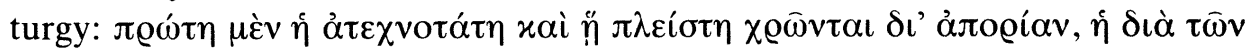

Versions of this paper were given at the APA meetings in Boston, and at Cornell University. I would like to thank the respective audiences for their encouraging and helpful comments. I would also like to thank Michael Simpson and the editor and referees of Classical Antiquity for their astute critiques.

1. References are to the edition of J. D. Denniston (Oxford, 1939).

2. See the bibliography of T. A. Tarkow, "The Scar of Orestes: Observations on a Euripidean Innovation," RhM 124 (1981) 143 n. 4. The scar is also discussed briefly by J. W. Halporn, "The Skeptical Elektra," HSCPh 87 (1983) 107-8.

(C) 1991 BY THE REGENTS OF THE UNIVERSITY OF CALIFORNIA 


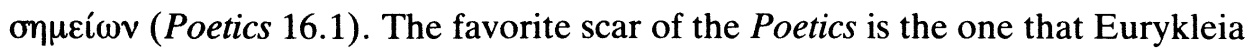
discovers on Odysseus, which has been widely acknowledged as the poetic antecedent for the Euripidean scar in Elektra ${ }^{3}$ The Odyssean scar is seen by accident and not, like the unsatisfactory Orestean scar, pointed out by one person to another as a means of confirming identity. The Poetics does not explicitly mention the scar in Elektra, but it does refer, pejoratively, to the signs and tokens of the Iphigeneia in Tauris (Poetics 16.6-8). The scar has no place in the Iphigeneia in Tauris, because Orestes there is anxious to be recognized and so readily offers Iphigeneia other shared memories of family history to convince her of his identity (810-27). The situation in the Elektra is more ambivalent, since Orestes has maintained his incognito and has apparently rejected the many opportunities for revelation that the dialogue has afforded him. ${ }^{4} \mathrm{He}$ must, therefore, be recognized by another, and so only external signs, rather than private memories, can be brought into play. The recognition is thus hedged around with difficulties; but the Poetics' formal emphasis prevents it from acknowledging that theatrical moments of discovery and recognition, whether accomplished by tokens or otherwise, often work not to establish or confirm identity, but to complicate it. In the case of Orestes' scar, I shall argue that the token both compares Orestes to a heroic exemplar and simultaneously denies him the possibility of living up to the claims thus implied for him. Far from being simply demonstrated, his identity is thus put into a problematic relation with the identity of another.

The heroic exemplar that I refer to is Odysseus, evoked at the moment in Odyssey 19.392-93 when Eurykleia threatens to sabotage his return by her discovery of his scar. In drawing this parallel I follow the majority of scholars who have commented at any length on this Euripidean scar (see n. 3 above). It would be difficult to exclude the Odyssey from an account of the scar, if only because of the immense cultural authority wielded in fifth-century Athens by Homeric epic. It is not the case, of course, that it is only the scar that betrays the presence (in absence) of Odysseus within the drama; Orestes already evokes Odyssean patterns of action in that he is returning to reclaim his palace and possessions and to put a stop to sexual irregularities, and these patterns of action condition any reading of Orestes' scar. But it may be useful to point how loaded with irony the scar can be even if it is not thought to evoke the shade of Odysseus. It seems to me almost comic that the definitive proof of identity is finally found to be one that has been available for Elektra's inspection throughout the entire scene. More significant perhaps is the immediate context in which the scar is noticed.

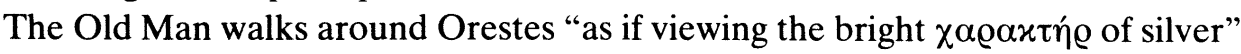
(558-59):

3. See, e.g., Denniston ad loc.; M. J. Cropp, Euripides' Electra, with Translation and Commentary (Warminster, Wilts., U.K. 1988) 134; and Tarkow (above, n. 2) 145-46 and n. 10.

4. See F. Solmsen, "Electra and Orestes: Three Recognitions in Greek Tragedy," Mededelingen der Koninklijke Nederlandse Akademie van Wetenschappen, Afd. Letterkunde, 30.2 (1967) 11. 


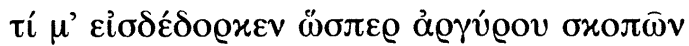
$\lambda \alpha \mu \pi \varrho o ̀ v ~ \chi \alpha \varrho \alpha x \tau \bar{\eta} \varrho^{\prime} ;$

Elektra had asked for a $\chi \alpha \varrho \alpha \chi \tau$ ๆ $\varrho$ that would convince her of Orestes' identity

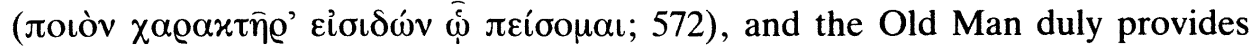
one; Orestes with the scar on his brow is a silver coin, stamped with the sign of its provenance and the guarantee of its validity. But Orestes, of course, will prove a false coin, not one that his pí $\lambda$ or can cash in to buy their safety. The play's discourse on the impossibility of measuring human worth in monetary terms (e.g., 367-76, 550-51, 938-44) exhibits variations on this theme.

The scar, then, is a far from simple token even if taken in isolation from its poetic predecessors. But the text itself discourages such abstraction, because the scar is produced in evidence after the failure of the hair, the footprints, and the bit of weaving - all clamorously "Aeschylean" tokens (518-45). Part of the effect of this perverse anagnorisis lies in the invitation to the audience to "recognize" the scene's poetic pedigree; similarly the episode of the scar demonstrates that the whole drama is "scarred," both made and marred by its inescapable relations to anterior texts.

If we accept the assumption that the scar of Orestes operates, at least in part, as a trace of the scar of Odysseus, the scar then indicates that the Odysseus of the epic tradition is being invoked as a means of representing the Euripidean Orestes. Critics have collectively demonstrated that evocations of other heroes of epic and dramatic tradition, such as the Homeric and Aeschylean Orestes, ${ }^{5}$ the athlete Achilles, ${ }^{6}$ and the Gorgon slayer Perseus, ${ }^{7}$ cluster around and implicitly comment upon the figure of Orestes in the Elektra. But the differences between these models and the Euripidean Orestes make them inappropriate, and ensure that Orestes fails to live up to the exemplars provided. Odysseus is thus one of the many traditional heroes that are, as it were, offered to Orestes by the drama and against which he can be measured and found wanting. If we accept, then, the general presence of Odysseus within the Elektra and the particular activation of the Odyssean scar in the moment of Orestes' recognition, it remains to investigate how the Euripidean scar measures its distance from the Homeric, and what this distance may signify.

The Odyssean narrative is, of course, lengthy and relaxed-it provided the starting point for Auerbach's theory of the eternal Homeric present ${ }^{8}$ - whereas the story of Orestes' scar is delivered in two lines. The brevity of the Euripidean

5. See S. Goldhill, Reading Greek Tragedy (Cambridge, 1986) 163-64, 247.

6. See G. R. Walsh, "The First Stasimon of Euripides' Electra," YClS 25 (1977) 277-89; K. C. King, "The Force of Tradition: The Achilles Ode in Euripides' Electra," TAPhA 110 (1980) 195212.

7. See M. O'Brien, "Orestes and the Gorgon: Euripides' Electra," AJPh 85 (1964) 13-39.

8. E. Auerbach, Mimesis: The Representation of Reality in Western Literature, tr. W. R. Trask (Princeton, 1968), 3-23. On Auerbach's claims for Homeric narrative, see M. Lynn-George, Epos: Word, Narrative and the Iliad (Atlantic Highlands, New Jersey, 1988) 8-13. 
account, taken with the factors cited above, may indicate that it offers itself as a metonymy for the Odyssean narrative. Similarly, the truncation of the story itself may correspond to the diminution of the story's elements. Each item in the Odyssean story-the hero's location, company, and activity—is systematically scaled down in its Euripidean counterpart. Odysseus has gone on a visit to his maternal grandfather, Autolykos, and is on Mount Parnassus, whereas Orestes

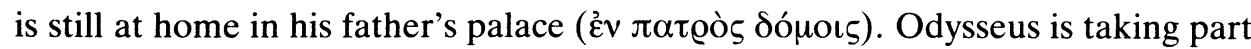
in a full-scale hunt, with other males (the sons of Autolykos), whereas Orestes is with his sister chasing a deer. Odysseus attacks and kills a wild boar, receiving the wound on his leg in the process; Orestes falls down and is bloodied while chasing the deer.

Why would the Elektra find it necessary to evoke, if fleetingly, the complex Odyssean narrative? Tarkow, noting these striking differences, writes that the scar "serves to remind us of the essentially unheroic fellow Euripides is portraying in Orestes" (1981: 147). His argument is that the differences between Orestes' scar and that of Odysseus constitute one of the ways in which the Elektra "probes . . . the very concept of traditional heroism" (1981: 144). This position is convincing, and feeds into a generally accepted account of the drama; but I want to elaborate on it and to suggest that the abbreviated Euripidean version of the Homeric narrative has further significance. I will first outline what I take to be the significance of the Odyssean boar hunt and then relate it to the Euripidean "hunt."

The story of Odysseus's scar is not told at random. While the scar proves Odysseus's identity to Eurykleia (and later on, to the swineherd and drover and to Laërtes), the episode that produced the scar helped to establish that identity in the first place. In saying this I do not mean only that the story is bound up with the way in which Autolykos named Odysseus (19.406), ${ }^{9}$ but also that it brings into play the important figure of the hunt. As Vidal-Naquet has extensively demonstrated, hunting occupies a special position in the fifth-century Athenian representation of male adolescence. ${ }^{10}$ The adolescent is figured as a solitary, guileful hunter, frequenting the asocial spaces of $\dot{\sigma} \sigma \alpha \tau \tau \alpha$ í and mountain. This representation need not, of course, have held for Homeric Ionia; what interests me here are the possible resonances of the Homeric text within fifth-century Athens, and hence the possible uses that the Elektra might make of the

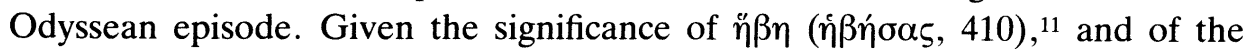

9. On the relations of the boar-hunt episode to Odysseus's name, see e.g., N. Austin, "The Function of Digressions in the Iliad," GRBS 7 (1966) 310; J. Clay, The Wrath of Athena: Gods and Men in the Odyssey (Princeton, 1983) 56-59.

10. P. Vidal-Naquet, "The Black Hunter and the Origin of the Athenian ephebeia," in R. L. Gordon, ed., Myth, Religion and Society (Cambridge, 1981); and in The Black Hunter: Forms of Thought and Forms of Society in the Greek World, tr. A. Szegedy-Maszak (Baltimore, 1986).

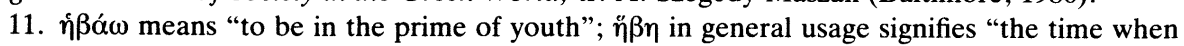
the beard first appears," and is a legal term in fifth-century Athens for a certain stage in male adolescence. 
hunt in the mountains (431-34) ${ }^{12}$ within this representation of adolescence, it is conceivable that the fifth-century Athenian culture could register this episode as in some sense a rite de passage, a critical stage in the transition from boyhood to the status of adult male.

There is an obvious difference, however, between the Odyssean hunt and the solitary hunt of the ephebe reconstructed by Vidal-Naquet. Boars are notoriously dangerous animals, and to hunt them successfully requires a large party of men, as in the paradigmatic case of the Kalydonian Boar. Such a boar hunt, as Vidal-Naquet notes, ${ }^{13}$ is a hunt of adult heroes, and can inculcate the skill in cooperative activity that is crucial to warfare. ${ }^{14}$ But if Odysseus is visiting Autolykos at the time of his $\eta \not \beta \eta$, that is, at the time when his beard first appears, then he is not yet a fully grown adult male. He is in fact the youngest participant, since Autolykos's sons are his uncles. ${ }^{15}$ Notwithstanding his position of structural inferiority, Odysseus proves himself among the other men by being the first to attack the boar. The boar hunt thus gives him the opportunity to prove his manhood and to pass successfully into the company of adult males, and the scar serves as a tangible reminder of this achievement.

To understand the specificity of Odysseus's success in this expedition, we might relate it to another available version of a boar hunt. Meleager, the hero of the Kalydonian Hunt, hunts like Odysseus with older men who are, again, his mother's brothers. Although he is victorious over the boar, he ends the expedition by killing his uncles and is himself destroyed by his mother. ${ }^{16}$ In Meleager's case, any attempt at socialization or at instilling group values ends in failure, whereas Odysseus makes the boar hunt the stage on which he performs successfully the act designed to establish his claim to adult manhood.

The timing of the Odyssey's recollection of this successful transition seems significant. Odysseus is, after all, in the bath, in the hands of Eurykleia, and it is well known that women and baths can be dangerous to returning heroes. ${ }^{17}$ The story of the boar hunt takes him out of this domestic feminine environment and suggests an image of proper heroic action. More important, it offers a version of the heroic persona that Odysseus needs to build for himself again out of his vulnerable position as a beggar in his own house. His achievement in the hunt can be seen as a guarantee of his future success against the Suitors.

The recognition of Odysseus thus turns on a scar that, once its story is

12. On the association of the ephebe with the antisocial space of the mountain, see VidalNaquet (above, n. 10) 1981: 154, 1986: 109.

13. On the nature of the boar hunt, see Vidal-Naquet (above, n. 10) 1981: 159, 1986: 118.

14. War is perhaps especially a cooperative activity if it is fought by the fifth-century hoplite phalanx.

15. I should perhaps note that if Autolykos were to reproduce for long enough, his youngest sons could be younger than his grandson.

16. On Meleager, see Iliad 9.565; Bacchylides, Ode 5.127-54.

17. I should point out that the Homeric death of Agamemnon differs considerably from the Aeschylean account. See Odyssey 11.404-20. 
unfolded, reveals him in the moment when he moves from boy to man, and when a heroic exploit assures him his proper place among his adult male peers. The point in the narrative where this recognition is effected finds Odysseus on the brink of another great exploit, and the recounting of the story can be seen to act as a guarantee of his continued success. The differences between this narrative and the Euripidean account systematically deprive Orestes of any analogous claim to manhood. While the story of Orestes' scar is in itself slightly comic, in comparison with the Homeric account it becomes positively damaging. Orestes is still in the domesticated space of $\pi \alpha \tau$ ¡ò $\delta$ ó $\mu$ or, unqualified as yet to leave home, and not even of an age when the two sexes are separated from each other to pursue their opposing destinies. Far from attempting any heroic exploit, he fails in the merely playful hunt that does engage him. The relation between the two scars is not only that between heroism and lack of it, as Tarkow argued, but also that between man's estate and childhood. The scar that effects the recognition of Odysseus proves him a man, both when it is acquired and again when its rediscovery confirms his status. The scar that identifies Orestes, conversely, marks him as a child. When the scar is acquired, Orestes is a child, and there is no discrepancy between his status and its marker; the scene of rediscovery, however, deliberately denies him a confirmation of his achieved manhood.

The point in the play at which Orestes is recognized is similarly significant in its relation to the Odyssean model. In the Euripidean as in the Odyssean account, the "hero" is recognized in the crucial period when he must forge a successful heroic identity out of fairly unpromising materials. Whereas the story of Odysseus's scar can be seen to assist in developing the required identity, Orestes' story rehearses not a manly deed but a childish accident. Orestes is recognized by the Old Man while he is in a domestic, "realistic" setting, as was Odysseus in the bath; but the story of Odysseus's scar removes him from this setting, whereas Orestes' story keeps him firmly within it. So far is the story of Orestes' scar from enacting a heroic scenario that it can almost be seen as a sudden indulgence in nostalgia, recreating a moment when Orestes still pos-

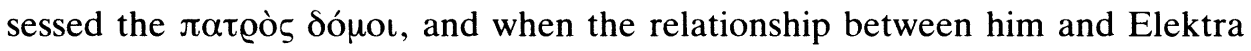
was not as fraught as it is about to become. ${ }^{18}$

What are the dramatic implications of the scar episode and the recollection of it here? At the moment when Orestes should be proving his manhood and his ability to take on the murderers of his father, the story of his scar locks him into a symbolic childhood. In the absence of a youthful heroic gesture that would have already proved his competence, Orestes appears ever more unqualified for the task that awaits him. The implicit comparison with what happens at a similar point in the Odyssey opens up still further the gap between the demands of

18. The drama as a whole elaborates an increasing tension between Orestes and Elektra. She has plans for him that he does not entirely appear to share; she is less hesitant than he about the matricide; the Chorus reproach her (1205) for urging him to the murder when he was unwilling. 
Orestes' traditional heroic role and his capacity to fulfil them. In this respect the story of the scar is consistent with the other strategies mobilized by the drama to disqualify Orestes, such as his anonymous arrival, his disinclination to be recognized (which necessitates the intervention of the scar), and his dishonorable attack on Aigisthos. The story of the scar can also be seen to resonate with later developments in the plot. Orestes' companion in his hunt is Elektra, and in the play as a whole he remains in her shadow, often depending on her thirst for vengeance to supply his motivation. At a critical juncture, she usurps the lines that were Pylades' in the Aeschylean Choephoroi (899-900), driving Orestes ruthlessly onwards to the matricide when he stops to question the wisdom of Apollo's command. The Chorus reproaches her, after the murders, for having incited her unwilling brother (1205). Furthermore, the story of the scar is set in

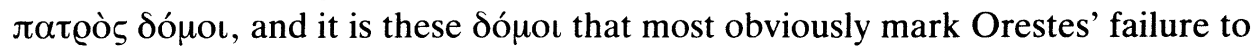
make the transition to full adulthood, because he is ultimately unable to replace Agamemnon as proprietor and head of the household. The present sister and the absent father determine the necessity of Orestes' vengeance, but even this act does not seem to allow Orestes to achieve a stature comparable to that of the heroic paradigms such as Odysseus. When the two children, Elektra and

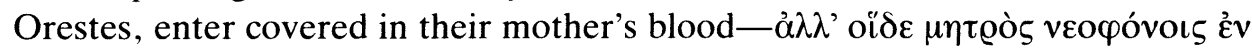

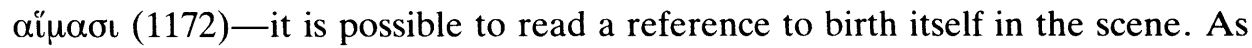
Tarkow noted, the murders can be seen to relate to the hunt of the fawn in various ways (1981: 146-47), ${ }^{19}$ and this in itself could suggest that the murders do not offer any escape from the symbolic childhood figured by the scar.

While the mother can thus be seen to block and confound her son's attempt at heroism, the father is also a significant figure in Orestes' failure to achieve heroic adult status. I have already indicated some of the resonances of $\pi \alpha \tau$ ○ò 5

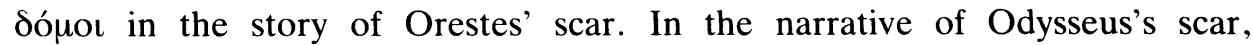
Autolykos names Odysseus (19.406) and endows him with some of his possessions (19.412). Since both men are liars and tricksters (19.395-98), the relation between them could be seen as one of hereditary identification. ${ }^{20}$ So far can they be identified that Autolykos is perhaps a more satisfactory father figure for Odysseus than Laërtes, who figures in the Odyssey chiefly to have a fictitious shroud woven for him (e.g., 2.96-102) and, in Book 24, to demonstrate by his poverty-stricken old age how dreadful are the effects of Odysseus's absence.

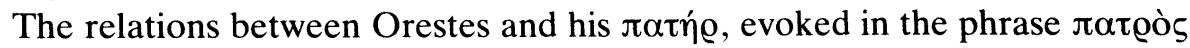

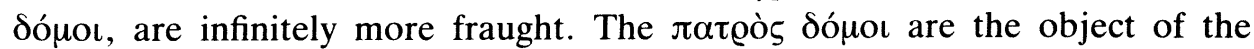
returning quest $(611,810)$, but are never regained; their loss is explicitly referred to in lines 588,1005 , and 1086 . The play deliberately keeps Orestes away from

19. Tarkow writes, "again with his sister . . . he pursues defenseless foes in the vicinity of his father's estates, after which . . his emotional happiness is drastically shaken and, we might say, scarred" (above, n. 2: 146).

20. See P. Pucci, Odysseus Polutropos: Intertextual Readings in the Odyssey and the Iliad (Ithaca, 1987) 89. 
his father's estates: he avoids entering them (94); the whole action takes place outside the city walls, and the Dioskouroi banish him at the end of the play $(1250-51,1316,1323)$. Before and even after the recognition scene, he is referred to as the son of his father, and on one occasion he is even, if we exploit an ambiguity offered by the text, the son of a father better than he ( $\alpha \mu \varepsilon i v o v o s$ $\pi \alpha$ toós, 338; see also 206, 330, 571, 880, 934-35, 1238). This repeated insistence on Orestes' paternity can be read ironically, for the ideal of identification between father and son is seriously questioned in the course of the play. Orestes himself draws attention to this issue in his lines on the difficulty of judging human worth: "I've seen a noble father breed a worthless son, / And good sons come of evil parents" (369-70). ${ }^{21}$ These lines obviously have a grotesque relevance for Orestes himself, whether or not he is thought to be aware of it (such awareness admittedly seems unlikely, given his ready use of $\alpha \xi \xi_{\llcorner} \varsigma$ at 391 ). They have a further resonance that can be gauged by reference to Hesiod. The likeness between father and son is a feature of the City of the Just in Works and Days (230-35):

Men whose justice is straight know neither hunger nor ruin, but amid feasts enjoy the yield of their labors.

For them the earth brings forth a rich harvest; and for them the top of an oak teems with acorns and the middle with bees, fleecy sheep are weighed down with wool, and women bear children who resemble their fathers.

The lack of such likeness is the index of a greater incoherence, a sign of humanity's degeneration (Works and Days 180-82):

Zeus will destroy this race of mortals when children are born gray at the temples.

Children will not resemble their fathers. ${ }^{22}$

Once the ideally unproblematic inheritance of paternal qualities is disrupted, nothing can be known with certainty, as Orestes goes on to demonstrate (373-79).

The scar of Orestes relates him firmly to Odysseus, the father, but in the Odyssey he is frequently invoked as a model for Telemachos, the son, to follow. ${ }^{23}$ The Elektra deliberately complicates the relation between model and copy in that Orestes must follow the example of both the son who helps to avenge his father, and the returning paternal hero. ${ }^{24}$ But despite the fact that Orestes returns, like

21. Translated by Philip Vellacott in Euripides: Medea and Other Plays (Harmondsworth, 1963; repr. 1973).

22. Translated by A. N. Athanassakis, Theogony, Works and days, Shield (Baltimore, 1983).

23. For instance, in Book 1 Athena urges Telemachos to imitate Orestes (298-300). On Orestes and Telemachos in the Odyssey, see Goldhill (above, n. 5) 147-48.

24. These complicated relations of imitation constitute something like a literary-historical joke, since Orestes is anterior to Telemachos in the Odyssey, but the Odyssey as a text is anterior to the Elektra. 
Odysseus, to claim what is rightfully his (the Farmer recognizes him, not Aigisthos, as xú @ıo 5 of Elektra, 259), his dead father continues to exert so much pressure on the language and plot of the play that he cannot break free from his subordinate position as the son. ${ }^{25}$ Odysseus, on his return, far from contending with paternal shades, is the absent, "dead" father of his text. Laërtes only appears in contexts where he is effectively unmanned by squalor and decrepitude.

Odysseus's scar plays a significant role in reestablishing relations between him and his father. Having been accidentally identified by Eurykleia, Odysseus himself displays the scar first to the swineherd and drover, at 21.217-20, and finally to Laërtes, in the last of the epic's proliferating recognition scenes. $\mathrm{He}$ recounts briefly the story of the scar (24.331-35) and follows it with another shared memory. He describes himself as a little boy trotting along beside his father in the orchard and learning the names of all the trees (24.336-39). This is a highly charged moment. The orchard story represents Odysseus as a child, in a position of dependence with regard to his father. But it is prefaced with the story of the scar, which, as we have noted, establishes his claim to be the man he is and the man he has proved himself to be against the Suitors. The orchard story, with its evocation of the youth of the trees that are still surrounding the speakers, tells of continuity and endurance; the scar tells of change, both in the physical body and in Odysseus's relations to his community. The combination of the two stories is compelling. The tale of the scar recounted briefly in the Elektra suggests only a continuity of failure, and Orestes never gets to tell his own story.

Stories from childhood, then, are deployed to identify both men. It is as though the hero has to return symbolically to the early period of his life before he can take up his adult inheritance. But Odysseus's childhood story is narrated to an enfeebled father, after he has proved himself by killing the Suitors in the palace. The story of the scar by which he is first recognized is one that proclaims him a man, tested by his peers. The moment of Orestes' recognition should have been similarly climactic; but the story of the scar that identifies him, in its refiguring of the Odyssean narrative, condemns him forever to the shadow of his father and sister, and inscribes him firmly into a childhood and a sonship that will destroy him.

\section{University of Texas}

25. Pace Halporn (above, n. 1), who argues that the familial relation is deliberately subtracted from the Elektra, and that the scar contributes to this change in emphasis. 